\title{
Analisis Kebocoran Tepi pada Glass lonomer Kaca dengan Penambahan Bioactive Glass Berbasis Silica dari Ampas Tebu
}

(Microleakage Analysis on Glass Ionomer Cements with Addition of Bioactive Glass Based on Silica from Sugarcane Bagasse)

Catur Putri Kinasih', Didin Erma Indahyani2 ${ }^{*}$, Izzata Barid ${ }^{2}$, Niken Probosari ${ }^{3}$,

1 Fakultas Kedokteran Gigi , Universitas Jember

2 Laboratorium Biologi Mulut, Bagian IImu Kedokteran Gigi Dasar, Fakultas Kedokteran Gigi, Universitas Jember

3 Bagian Pedodonsia, Fakultas Kedokteran Gigi, Universitas Jember

\begin{abstract}
Abstrak
Penggunaan semen ionomer kaca (SIK) mempunyai keterbatasan misalnya sensitif dengan air yang berperan pada pembentukan mikroleakeage akibat terjadinya shrinkage dan kerapuhan. Pencampuran 0,04\% bioactive glass nano silica (BAG) dengan SIK meningkatkan bioaktivitasnya melalui pembentukan hydroxycarbonate apatite (HCA). Hal tersebut penting pada pencegahan terjadinya marginal gap. Penelitian ini bertujuan untuk menentukan perbedaan rata rata nilai microleakage antara SIK dan SIK yang ditambahkan dengan BAG dari ampas tebu. Dalam penelitian ini pembuatan BAG dari ampas tebu, pemilihan sampel gigi sapi (24 gigi), secara random dikemlompokan menjadi 4 kelompok, kelompok 1, SIK; kelompok 2, SIK+vaselin, kelompok 3, SIK+BAG; Kelompok 4 SIK+BAG+vaselin. Semua sampel siapkan, dilakukan restorasi sesuai dengan bahan yang ditentukan (sesuai kelompoknya) dan disimpan dalam methylen blue $1 \%$ pada suhu $370 \mathrm{C}$ selama 24 jam. Rata rata nilai microleakage dilakukan skoring yang tergantung pada masuknya methylen blue didinding oklusal dan gingiva. Rata rata nilai microleakage SIK+BAG lebih kecil dibandingkan dengan SIK, tetapi tidak ada perbedaan yang signifikan.
\end{abstract}

Kata kunci: ampas tebu, bioactive glass nano silica, microleakage, semen ionomer kaca,vaseline

\section{Abstract}

The use of Glass lonomer Cement (GIC) has some limitation, such as water sensitivity which leads to formation of microleakage due to shrinkage and brittle. Incorporation of 0.04 wt\% bioactive glass nano silica (BAG) with GIC enhances its bioactivity to forming hydroxycarbonate apatite (HCA) leading to preventing of marginal gap formation. The objective this study was To determine the difference of microleakage means value between GIC and GIC which has been added by BAG from bagasse. In this study making BAG from bagasse, than choose the samples (24 bovine) randomly and grouping them to be 4 groups, which are group 1, GIC; group 2, GIC+Vaseline, group 3, GIC+BAG; group $4 \mathrm{GIC}+B A G+V a s e l i n e$. All of the samples are supposed to be preparation, placed of the restoration, and stored in the aquadest then methylen blue $1 \%$ in sequence at $37^{\circ} \mathrm{C}$ until $24 \mathrm{~h}$. The microleakage means value is decided by scoring system depend on the penetration of methylen blue 1\% at occlusal wall and gingival wall. The microleakage means value on GIC+BAG is smaller than GIC, but their differences were not significant.

Keywords: bioactive glass nano silica, glass ionomer cement, microleakage, surgane bagasse, vaseline

Korespondensi (Correspondence) : Didin Erma Indahyani, Universitas Jember email: didinermae.fkg@unej.ac.id

Bahan bioactive glass didefinisikan sebagai bahan yang didesain untuk menginduksi aktifitas biologis yang spesifik. Bahan tersebut mengalami reaksi permukaan yang spesifik ketika diimplementasikan pada tubuh dan berperan pada pembentukan lapisan hidroksiapatit-like yang berfungsi pada pembentukan ikatan antara jaringan keras dan lunak!. Bioactive glass membentuk lapisan bioactive pada permukaan yang berkontak dengan jaringan hidup yang dikenal dengan hydroxyapatite (HCA), yang sama dengan fase mineralisasi pada jaringan keras manusia. Mineralisasi akan sangat tinggi bila menggunakan bioactive glass yang partikelnya berukuran nano. Hal tersebut menunjukan ukuran partikel berperan penting pada aplikasi klinik². Dibidang kedokteran gigi, pengembangan bioactive glass terus meningkat, terutama ke arah remineralisasi, treatment hipersensitivitas juga sebagai bahan antibakteri3. Akan tetapi bahan komposit dengan kandungan bioactive glass yang tinggi mempunyai sifat mekanis yang rendah misalnya pada modulus elastisitas dan compression strength 4 .

Glass ionomer semen merupakan bahan tumpatan gigi yang mempunyai beberapa kelebihan yaitu berikatan langsung dengan gigi oleh adanya interaksi natural apatit dengan kelompok karboksilat dari polyalkenoic acid, sifat bioaktivitasnya yang bagus, pelepasan fluoride dan aksi antibakterinya. Oleh karena itu glass ionomer akan mempertinggi remineralisasi fluorapatit5. GIC memiliki beberapa kelemahan misalnya kerapuhannya relatif tinggi dan sensitif terhadap kelembaban selama tahap awal seting. Untuk meningkatkan kekuatan mekanik GIC, dilakukan modifikasi dengan polyelectrolyte atau bubuk kaca. Namun bahan ini juga memiliki kerapuhan yang relatif tinggi dan sensitif pada kelembaban. Hal tersebut menyebabkan ikatan antara GIC dan gigi lemah. Ikatan kimia yang lebih kuat antara GIC dan gigi oleh karena adanya pembentukan interlayer apatit, misalnya adanya fluor, sehingga terjadi ikatan fluor 
apatit. Namun, GIC konvensional, dianggap sulit untuk membentuk lapisan apatit seperti itu karena pelepasan asam poliakrilat (PAA) dari GIC menurunkan $\mathrm{pH}$ dan menghambat pembentukan apatitb. Pembentukan kristal apatit ini akan tertunda atau bahkan gagal oleh karena protein akan melekat pada permukaan semen. Adesi protein pada permukaan tersebut menghambat pertumbuhan hidroksi apatit5. Penambahan bahan bioactive glass pada glass ionomer semen ditujukan untuk meningkatkan dan mempercepat proses mineralisasi secara structural. Sel hanya dapat melekat pada bahan bioactive. Glass ionomer semen bukan bahan bioactive. Jika bahan bioactive diresorbsi oleh tubuh, maka apaitit akan terdeposisi kembali dan protein serta factor pertumbuhan dapat melekat pada bahan remineralisasi. Oleh karena itu apatit akan mampu berinteraksi dengan struktur dentin dan mempertinggi ikatan melalui mechanical interloking, dan protein akan ditarik dan terjadi percepatan regenerasi?. Selain itu glass ionomer kaca peka terhadap kondisi lembab dan kondisi kering. Kondisi kering menyebabkan pelarut semen ionomer kaca menguap, sehingga semen ionomer kaca mudah retak atau menyusut. Penyusutan yang terjadi, akan menyebabkan kebocoran tepi ${ }^{8}$. Kebocoran tepi adalah celah mikro yang terbentuk di antara permukaan bahan restorasi dan dinding kavitas. Kebocoran tepi menyebabkan debris, makanan, dan saliva, masuk ke dalam celah mikro tersebut, sehingga menyebabkan kegagalan restorasi sebanyak $86 \% 9,10$. Dampak dari kebocoran tepi tersebut adalah karies sekunder, rasa sensitif, dan perubahan warna pada daerah margin restorasi ${ }^{11}$. Tujuan penelitian ini adalah untuk menganalisis penambahan pengaruh penambahan bioactive glass berbasis silica ampas tebu pada glass ionomer kaca terhadap tingkat kebocoran tepi dan pembentukan hidroksi karbonat apatit.

\section{METODE PENELITIAN}

Penelitian ini diawali dengan pembuatan bioactive glass nano silica dari ampas tebu. Ampas tebu dikeringkan dan diabukan selama 2 hari di dalam muffle furnice bersuhu $900^{\circ}$ C. Sebanyak 25 gram abu ampas tebu, dicuci dengan $150 \mathrm{~mL} \mathrm{HCL}$ $0,1 \mathrm{M}$ dengan cara memasukkan abu ampas tebu dan larutan $\mathrm{HCL}$ ke dalam tabung erlenmayer, kemudian mengaduk campuran tersebut secara otomatis menggunakan alat pengaduk magnet selama 60 menit, kemudian mendiamkannya selama 1 malam, kemudian disaring menggunakan kertas saring whatmann no. 42. Hasilnya dibilas dengan akuades hingga $\mathrm{pH}$ abu ampas tebu menjadi netral $(7,0)$. Abu ampas tebu dikeringkan dalam oven bersuhu $110^{\circ} \mathrm{C}$ selama 2 jam. Sebanyak 10 gram abu ampas tebu dicampurkan dengan $60 \mathrm{~mL}$ larutan
$\mathrm{NaOH} 2 \mathrm{~N}$ di dalam tabung erlenmayer, dan diaduk sampai mendidih selama 60 menit, kemudian disaring menggunakan kertas saring whatmann no. 42. Hasilnya dikeringkan kembali dalam oven bersuhu $110^{\circ} \mathrm{C}$ selama 2 jam. 5 gram natrium silikat yang sudah terbentuk, dicampur dengan akuades ( $15 \mathrm{~mL}$ ) dan diaduk. Etanol $96 \%(2,5 \mathrm{~mL})$ ditambahkan sampai larutan berubah menjadi jernih dan $\mathrm{HNO}_{3} 2 \mathrm{M}$ ditambahkan tetes demi tetes sampai $\mathrm{pH}$ larutan menjadi netral. Campuran tersebut terus diaduk selama 60 menit. Phosporus pentoxide (0.5 gram) ditambahkan dan terus diaduk selama 45 menit. Setelah 45 menit, kalsium nitrat tetrahidrat (4.1 gram) ditambahkan dalam campuran dan terus diaduk selama 105 menit. Hasil dari adukan campuran tersebut kemudian didiamkan pada suhu ruang selama 5 hari, dikeringkan dalam oven bersuhu $60^{\circ} \mathrm{C}$ selama 3 hari, dan dikeringkan dalam muffle furnace bersuhu $600^{\circ} \mathrm{C}$ selama 5 jam, dilanjutkan dengan suhu $1000^{\circ} \mathrm{C}$ selama 2 jam $^{10}$. Bioactive glass nano silica dari ampas tebu yang sudah jadi, dicampurkan sebanyak 0,04 w $\%$ dalam semen ionomer kaca secara manual (dimasukkan ke dalam botol kaca dan dikocok)"11.

Penelitian ini menggunakan elemen gigi insisivus sapi sebanyak 24 buah, dengan kriteria tidak karies, tidak fraktur, tidak abrasi bagian labial, diambil dari rahang bawah sapi berumur 15 tahun, dan disimpan dalam larutan fisiologis kurang dari 2 bulan $^{12}$. Sampel dipilih secara acak dan dikelompokkan menjadi 4 kelompok yaitu kelompok 1 dan kelompok 2, sampel ditumpat dengan semen ionomer kaca (SIK), sedangkan kelompok 3 dan kelompok 4 ditumpat dengan semen ionomer kaca yang dicampur dengan bahan bioactive glass nano silica dari ampas tebu (SIK+BAG).

Persiapan gigi

Sampel gigi ditanam dalam model gips setinggi servikal, kemudian dipreparasi berbentuk kavitas bulat dengan diameter 3 $\mathrm{mm}$ dan kedalaman $2 \mathrm{~mm}$ pada sepertiga tengah bagian labial. Setiap kavitas dibersihkan dengan akuades dan dikeringkan dengan cotton pellet, kemudian diulasi asam poliakrilat $25 \%$ dan ditunggu sampai 20 detik. Kavitas dibersihkan dengan akuades dan dikeringkan dengan cotton pelle ${ }^{13}$.

Semen ionomer kaca dimanpulasi dengan perbandingan bubuk dan cairan asam poliakrilat (1:1) di atas paper pad. Bahan kemudian dimasukan dalam kavitas. Kelompok 1 dan 3 dipadatkan dengan cellulosa strip yang telah diulasi vaselin, sedangkan kelompok 2 dan kelompok 4 dipadatkan dengan cellulosa strip tanpa diulasi vaselin. Setelah itu sampel direndam dalam akuades dan dimasukkan ke dalam inkubator bersuhu 370 selama 24 jam. Sampel kemudian dikeluarkan dari inkubator dan dilepaskan dari model gips. Seluruh permukaan sampel diulasi varnish/ cat kuku sebanyak 2 lapis, kecuali pada permukaan 
tumpatan dan $1 \mathrm{~mm}$ di sekitar permukaan tumpatan. Selanjutnya sampel direndam dalam larutan metilen biru $1 \%$ dan dimasukkan ke dalam inkubator bersuhu $370 \mathrm{C}$ selama 24 jam. Sampel kemudian dikeluarkan dari inkubator dan dipotong dari arah labial tepat di tengah tumpatan'4. Selanjutnya sampel ditanam dalam model gips setinggi servikal, kemudian dipreparasi berbentuk kavitas bulat dengan diameter $3 \mathrm{~mm}$ dan kedalaman $2 \mathrm{~mm}$ pada sepertiga tengah bagian labial. Setiap kavitas dibersihkan dengan akuades dan dikeringkan dengan cotton pellet, kemudian diulasi asam poliakrilat $25 \%$ dan ditunggu sampai 20 detik. Setelah 20 detik, kavitas dibersihkan dengan akuades dan dikeringkan dengan cotton pellet'i3.

Kebocoran tepi diamati di bawah mikroskop cahaya dengan perbesaran 50 kali, dan pengukuran nilai kebocoran tepi ditetapkan menggunakan sistem skoring sebagai berikut: 15

1. Skor $0=$ tidak ada penetrasi larutan metilen biru

2. Skor $1=$ terdapat penetrasi Iarutan metilen biru sepanjang kurang dari $1 / 2$ panjang dinding oklusal atau dinding gingival

3. Skor $3=$ terdapat penetrasi larutan metilen biru sepanjang lebih dari $1 / 2$ panjang dinding oklusal atau dinding gingival

4. Skor $4=$ terdapat penetrasi larutan metilen biru sepanjang dinding oklusal atau dinding gingival hingga mencapai dinding pulpa.

Hasil pengamatan dianalisis secara statistic menggunakan one way anova dan least significant difference) dengan signifikansi $(p<0,05)$.

\section{HASIL PENELITIAN}

Berdasarkan pengamatan yang telah dilakuka, didapatkan hasil rerata nilai kebocoran tepi pada 4 kelompok adalah kelompok $1=1,67$, kelompok $2=1,5$, kelompok $3=1,25$, dan kelompok $4=1,5$. Hasil rerata kebocoran tepi pada 4 kelompok tersebut tersaji pada diagram batang (gambar 1). Secara mikroskopis kebocoran tepi tampak jelas pada kelompok tanpa bioactive glass. Penambahan bioactive glass pada semen ionomer kaca terlihat gambaran methilen blue yang lebih sedikit. Penggunaan bahan vaselin pada waktu pemadatan, juga mengurangi tingkat kebocoran tepinya (dapat dilihat pada gambar 2).

Rerata nilai kebocoran tepi semen ionomer kaca lebih besar daripada rerata nilai kebocoran tepi semen ionomer kaca yang dicampur dengan bahan bioactive glass nano silica dari ampas tebu, namun hasil uji uji one way anova menunjukkan nilai signifikansi $=0,454$ dan uji least significant difference pada tabel 1 menunjukkan hasil signifikansi ( $p>0,05)$, sehingga dapat dikatakan bahwa perbedaan rerata nilai kebocoran tepi tersebut tidak signifikan atau tidak bermakna.

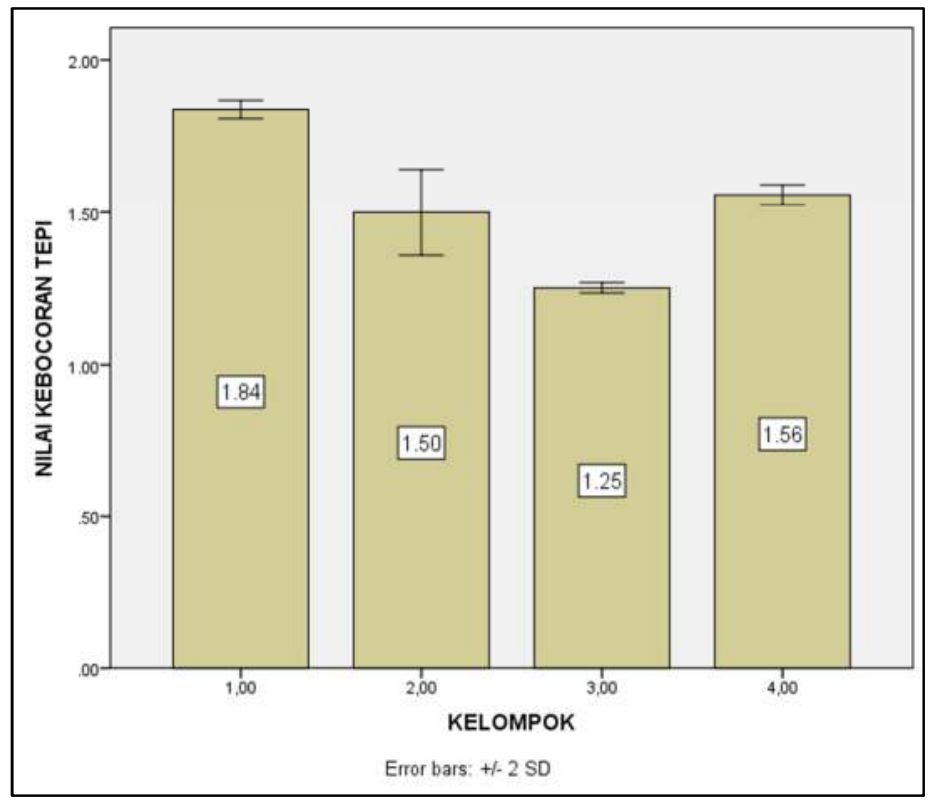

Gambar 1. Histogram perbedaan rerata nilai kebocoran tepi 

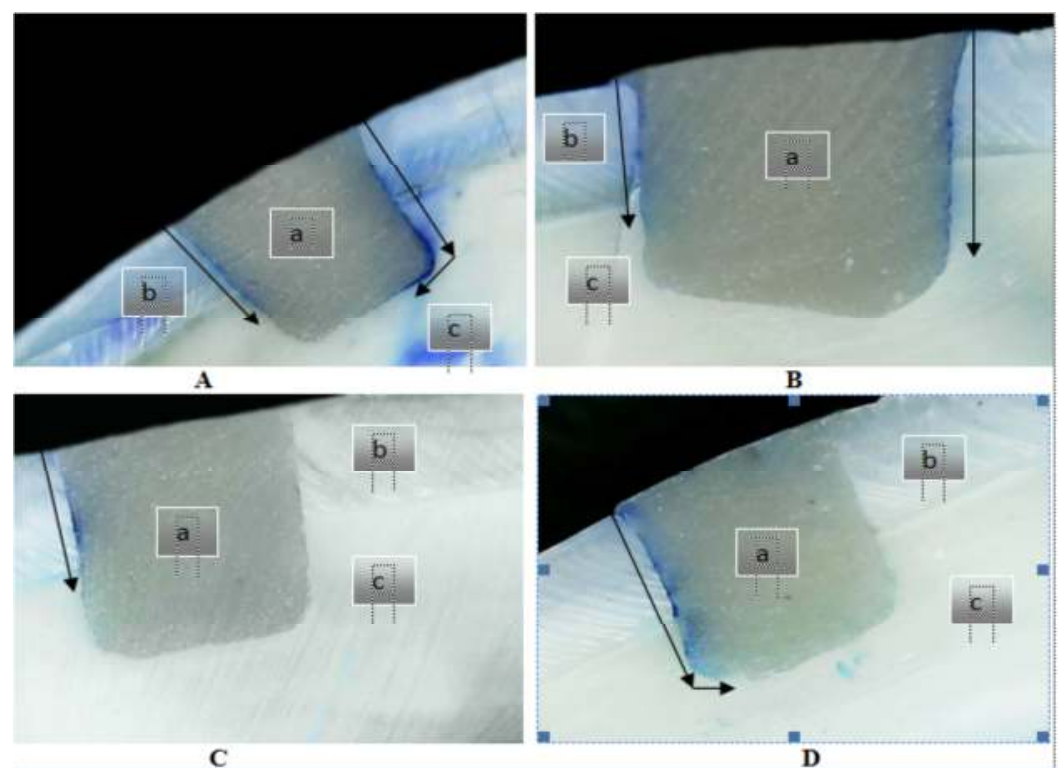

Gambar 2. Foto sampel setelah direndam dalam larutan metilen biru 1\%, (perbesaran 50x), $A=G \mid$ kelompok 1, B = kelompok 2, C = kelompok 3, D = kelompok 4.

( $a$, restorasi; b, enamel; c, dentin; tanda panah, kedalaman penetrasi larutan metilen biru $1 \%$ menunjukkan skor kebocoran tepi dinding oklusal-dinding gingival pada gambar A, B, C, dan D berturut-turut $=2-3,2-2,2-0,3-0$ )

Tabel 1. Hasil Analisis Perbandingan antar Kelompok dengan Uji Least Significant Difference

\begin{tabular}{ccccc}
\hline \multirow{2}{*}{ Kelompok } & \multicolumn{5}{c}{ Nilai P } \\
\cline { 2 - 5 } & 1 & 2 & 3 & 4 \\
\hline 1 & - & 0,257 & 0,135 & 0,257 \\
3 & 0,257 & - & 0,701 & 1,000 \\
4 & 0,134 & 0,701 & - & 0,701 \\
\hline
\end{tabular}

\section{PEMBAHASAN}

Semen ionomer kaca merupakan suatu bahan restorasi yang dapat melekat kepada bahan polar seperti tulang, dentin, dan enamel. Bahan ini tidak dapat melekat pada logam mulia maupun porselen. Perlekatan semen ionomer kaca dengan struktur gigi dapat terjadi akibat kelompok karboksilat (ion - ion asam polimer) menggantikan fosfat dalam hidroksiapatit. Fosfat dalam hidroksiapatit merupakan struktur utama dari gigi, sehingga dengan menggantikan fosfat maka ikatan semen ionomer kaca dengan struktur gigi sangat kuat'b. Akan tetapi perlekatan semen ionomer kaca secara structural akan mudah terlepas, oleh karena terjadinya penundaan pembentukan hidroksiapatitnya. Beberapa factor yang menyebabkan penundaan pembentukan hidroksi apatit adalah adanya kesempatan protein untuk mengikat permukaan semen kaca, yang menghambat proses mineralisasi ${ }^{5}$. Kim, dkk ${ }^{17}$., menyatakan bahwa tidak mungkin terjadi remineralisasi di daerah dentin yang karies setelah di lakukan tumpatan glass inomer. Proses mineralisasi memerlukan bahan untuk terjadi nukleasi heterogen (melibatkan teori epitaksi), misalnya kolagen. Nukleasi heterogen memicu pembentukan Kristal hidroksiapatit. Pada waktu terjadi karies, kolagen akan hilang dan habis. Penggunaan uptake mineral saja tidak cukup sukses untuk melakukan proses mineralisasi. Hal ini menerangkan pada hasil penelitian ini bahwa pada kelompok semen ionomer kaca, menunjukan adanya kebocoran tepi.

Semen ionomer kaca mengalami 3 fase dalam reaksi settingnya, yakni fase pelepasan ion, fase hidrogel, dan fase polysalt gel. Fase pelepasan ion terjadi ketika bubuk dan pelarut mulai dicampurkan (mixing). Asam yang terkandung dalam pelarut semen ionomer kaca bereaksi dengan ion - ion yang terdapat dalam bubuk semen ionomer kaca untuk membentuk silika gel. Fase selanjutnya adalah fase hidrogel. Fase ini merupakan fase pengerasan awal semen ionomer kaca akibat terjadinya ikatan cross - link antara kation bubuk dan anion pelarut asam polimer. Fase ini terjadi 5 - 10 menit setelah bubuk dan pelarut semen ionomer kaca dicampurkan. Fase polysalt gel merupakan fase ketiga, yakni fase pengerasan akhir dan pematangan semen ionomer kaca (final setting) ${ }^{18}$. semen ionomer kaca bersifat sangat sensitif terhadap kondisi lembab atau kering pada fase pengerasan awal (fase hidrogel). Kondisi kering akan menyebabkan semen ionomer kaca mengalami sineresis 
(kehilangan air karena penguapan cairan). Sineresis yang terjadi akan menyebabkan bahan restorasi ini retak atau mengkerut, sehingga timbul celah mikro (kebocoran tepi). Keadaan itu juga memicu terjadinya kebocoran tepi pada tumpatan semen ionomer kaca. Kondisi ini dapat ditangani dengan cara memberikan lapisan vaselin, varnish, cat kuku bening, atau resin di atas semen ionomer kaca selama 24 jam setelah pengaplikasian semen ke dalam kavitas 19 . Fenomena tersebut dapat dilihat pada hasil penelitian ini, bahwa pemberian vaselin diatas permukaan semen ionomer kaca, mengurangi terjadinya kebocoran tepi tumpatan. Vaselin mengahalangi menyerapan air oleh bahan semen ionomer kaca. Penyerapan air menyebabkan semen ionomer kaca berekspansi, sehingga kebocoran tepi yang terjadi, tidak sebesar kebocoran tepi sebelum perendaman dalam akuades 20 .

Pada kelompok dengan tambahan bioactive glass, menunjukan kebocoran tepinya lebih sedikit dari pada kelompok semen ionomer kaca saja. Beberapa penelitian menunjukan bahwa bioactive glass beperan pada remineralisasi jaringan keras. Tahap remineralisasinya dimulai dengan pelepasan ion, pembentukan kelompok silanol, serta pengendapan kalsium dan fosfat untuk membentuk lapisan hydroxycarbonate apatite (HCA). Ukuran partikel bioactive glass dapat mempengaruhi proses remineralisasi ini. Semakin kecil ukuran bioactive glass, maka semakin cepat proses remineralisasinya. Bahan bioactive glass akan segera bereaksi untuk membentuk HCA setelah berkontak dengan air, saliva, atau cairan tubuh lainnya ${ }^{21}$. Pembentukan HCA ini adalah kurang dari 2 jam setelah bioactive glass silica berkontak dengan cairan tubuh22.

Perbedaan rerata nilai kebocoran tepi antara kelompok 1, kelompok 2, kelompok 3, dan kelompok 4 pada tabel 1 menunjukkan hasil yang tidak signifikan atau tidak bermaknaPerbedaan rerata nilai kebocoran tepi yang tidak signifikan, dapat pula dikarenakan pada kelompok 3 dan kelompok 4 terjadi pembentukan lapisan HCA baru untuk mencegah terjadinya kebocoran tepi pada semen ionomer kaca, namun pembentukan lapisan HCA baru tersebut hanya sebatas lapisan HCA bary yang tipis dan halus ${ }^{11}$, sehingga kebocoran tepi yang tejadi tidak dapat sepenuhnya dicegah.

Penambahan bioactive glass berbasis silika dari ampas tebu pada semen ionomer kaca, menghambat terjadinya kebocoran tepi, oleh karena bioactive glass mampu menstimulasinya terjadinya nukleasi hidroksi apatit, dengan terbentuknya hidroksikarbonat apatit.

\section{DAFTAR PUSTAKA}

1. Rahamana MN., Delbert ED, Balb BS, Fuc $Q$, Junga $S B$, Bonewalde LF, and Tomsiac
AP, Bioactive glass in tissue engineering, Acta Biomater . $2011 ; 7(6)$ : 2355-73

2. Ferreira $G$, Inés $M$. Bioactive materials in dentin remineralization Odontoestomatología. 2016; 18(28).

3. Abbasi Za, Bahrololoom MEa, Shariat $\mathrm{MHa}$, Bagheri Rb. Bioactive Glasses in Dentistry: A Review, Journal of Dental Biomaterials. 2015; 2(1)

4. Li Y., 2014, Investigating The Structure, Solubility and Bioactivity of $\mathrm{Na} / \mathrm{Sr}$ Bioactive Glasses/Glass-Ceramics. Thesis. The Faculty of Alfred University, New York.

5. Kokubo T., Takadama H. How useful is SBF in predicting in vivo bone bioactivity?. Biomaterials, 2006; 27 (15) : 2907-15.

6. Chen S, Cai Y, Engqvist H, Xia W. Applied Enhanced bioactivity of glass ionomer cement by incorporating calcium silicates, Biomatter. 2016; 6(1), 13 pages

7. De Caluwe T, Vercruysse CWJ, Ladik I., Convents R., Declerca H., Martens LC., Verbeeck RMH. Addition of bioactive glass to glass ionomer cements : Effect on the physic-chemical properties and biocompatibility, Dental Materials. 2017; 33 : 186-203.

8. Kamalak, H., Mumcu A., Altin S. The Temperature Dependence of Microleakage between Restorative and Pulp Capping Material by Cu Diffusion. The Open Dentistry Journal. 2015; 9: 140 5.

9. Tambahani AM., Wicaksono D., Tumewu E. Gambaran Kerusakan Gigi Pasca Restorasi Komposit pada Siswa SMA Negeri 1 Manado. Jurnal e - GiGi (eG). 2013; 1(2): $121-8$.

10. Adams LA., Enobong RE., Rafiu OS., Aderemi O. Sol - Gel Synthesis of $\mathrm{SiO} 2-$ $\mathrm{CaO}$ - Na2O - P2O5 Bioactive Glass Ceramic from Sodium Metasilicate. New Journal of Glass and Ceramics. 2013; 3: $11-5$.

11. Mabrouk M., Selim M. M., Baharei H., El Gohary, M. I. Effect of Incorporation of Nano Bioactive Silica Into Commercial Glass lonomer Cements (GIC). Journal of Genetic Engineering and Biotechnology. 2012; 10: $113-9$.

12. Dorland W. Dorland's llustrated Medical Dictionary. Terjemahan Huriawati Hartanto, dkk. Kamus Kedokteran. Edisi 26. Jakarta: EGC, 2002. hal. 771. 
13. Lestari, S., Dwi W. A. F., Hidayatul F. Kebocoran Tepi Restorasi Semen Ionomer Kaca dengan Bahan Fuji II, Fuji VII, (White) dan Fuji VII (Pink). Stomatognatic (JKG UNEJ). 2012; 9 (1): $23-7$.

14. Aviandani MJ., Elly M., Mohammad Y. Perbedaan Kebocoran Tepi Tumpatan Semen lonomer Kaca dengan Pengadukan secara Mekanis Elektrik dan Manual. Jurnal PDGI. 2012; 61(3):81-7.

15. Gupta SK., Jaya G., Vidya S., Vasudev B., Shashi RA. Comparative Evaluation of Microleakage in Class $\vee$ Cavities Using Various Glass Ionomer Cements: An In Vitro Study. Journal of Interdiciplinary Dentistry. 2012; 2: 164 -9

16. Khoroushi M. dan Fatema K. A Review of Glass Ionomers: From Conventionel Glass Ionomer to Bioactive Glass Ionomer. Dental Researh Journal. 2013; 10 (4): $411-$ 20.

17. Kim YK, Yiu CKY, Kim JR, GU L, Kim SK, Weller RN, Pashley DH, and Tay FR. Failure of a Glass Ionomer to remineralize
Apatite-depleted Dentin, J Dent Res.2010; 89(3): 230-5.

18. Apsari A., Elly M., Mohammad Y. Perbedaan Kebocoran Tepi Tumpatan Resin Komposit Hybrid. Jurnal PDGI. 2009; 58(3): $1-7$.

19. Rizzante FAP., Rafel SC., Juliana Fr SB., Gisele MC., Carla CG., Adilson YF. Indication and Restorative Techniques for Glass lonomer Cements. RSBO. 2015; 12 (1): $79-87$.

20. Rossetti PHO., Accacio LdV., Richardo MdC., Mario FDG., Luiz FP. Jappl Oral Sci. 2008; 16 (1): $64-9$.

21. Prabhakar A. dan Veena A. Comparison of the Remineralizing Effects of Sodium Fluoride and Bioactive Glass Using Bioerodible Gel System. Journal of Dental Research, Dental Clinics, Dental Prospects. 2009; 3(4): $117-21$.

22. Farooq I., Zonera I., Umer F., Ali L., Humera A. Bioactive Glass : A Material For The Future. World Journal of Dentistry. 2012; 3(2) : $199-201$. 